\title{
Cloning Polymerase Chain Reaction (PCR) Products: TOPO TA Cloning
}

\author{
Michael R. Green and Joseph Sambrook
}

This protocol describes the use of TOPO-activated TA vectors for cloning. Manufacturers of cloning kits provide excellent manuals that explain in detail what to do and why to do it. This makes TOPO cloning easy, but not foolproof. When setting up TOPO cloning for the first time, set up a trial experiment as described here.

\section{MATERIALS}

It is essential that you consult the appropriate Material Safety Data Sheets and your institution's Environmental Health and Safety Office for proper handling of equipment and hazardous materials used in this protocol.

RECIPES: Please see the end of this protocol for recipes indicated by $<R>$. Additional recipes can be found online at http://cshprotocols.cshlp.org/site/recipes.

\section{Reagents}

\section{Agarose gels}

Chemically competent One-Shot TOP10 bacteria (available from Life Technologies [at the time of this initial writing]) or equivalent

Life Technologies' standard TOPO kits contain preparations of chemically competent or electrocompetent OneShot TOP10 bacteria. However, there is nothing special about these preparations of bacteria. Chemically competent preparations of DH10B, a close relative of TOP10, work equally well.

Plasmid

Restriction endonucleases

$\mathrm{SOB}<\mathrm{R}>$, $\mathrm{SOC}<\mathrm{R}>$, or $\mathrm{LB}<\mathrm{R}>$ agar plates containing the appropriate antibiotic, prewarmed SOC medium $<\mathrm{R}>$

Solution containing $1.2 \mathrm{M} \mathrm{NaCl}$ and $0.06 \mathrm{M} \mathrm{MgCl}_{2}$

Target DNA ( $25 \mathrm{ng} / \mathrm{mL})$, amplified by PCR catalyzed by Taq

TOPO-activated TA vector $(10 \mathrm{ng} / \mu \mathrm{L})$

Equipment

Container filled with ice

Shaking incubator $\left(37^{\circ} \mathrm{C}\right)$

Water baths (preset to $37^{\circ} \mathrm{C}, 42^{\circ} \mathrm{C}$, and the optimal temperature [s] for restriction enzyme digestion)

From the Molecular Cloning collection, edited by Michael R. Green and Joseph Sambrook.

(C) 2021 Cold Spring Harbor Laboratory Press

Cite this protocol as Cold Spring Harb Protoc; doi:10.1101/pdb.prot101311 
1. Set up a $50 \mu \mathrm{L}$ Taq-catalyzed PCR as using a combination of template:primers that has generated an abundance of amplified product 250-750 nucleotides in length in a recent experiment in your laboratory.

2. Check that the amplification reaction has generated a single discrete product of the expected size by analyzing an aliquot $(10 \mu \mathrm{L})$ of the PCR product by gel electrophoresis.

If the amplification reaction has generated more than one species of DNA or other PCR artefacts (e.g., primer dimers, smeary bands), it is best to set up another gel to purify the DNA species of interest using, for example, the Millipore Montage DNA Gel Extraction kit or Sigma-Aldrich GenElute.

3. Without delay, set up a TOPO cloning test reaction as follows, using solutions provided by the manufacturer of the kit.

Mix:

Amplified DNA

$1.0 \mu \mathrm{L}$

$\mathrm{NaCl}(1.2 \mathrm{M}) / \mathrm{MgCl}_{2}(0.06 \mathrm{M})$

$1.0 \mu \mathrm{L}$

Sterile $\mathrm{H}_{2} \mathrm{O}$

$3.0 \mu \mathrm{L}$

TOPO-activated TA vector $(10 \mathrm{ng} / \mu \mathrm{L})$

$1.0 \mu \mathrm{L}$

Set up a control reaction (Background Control) in which the amplified DNA is replaced by $1 \mu \mathrm{L} \mathrm{of} \mathrm{H}_{2} \mathrm{O}$. Set up a third transformation (Transformation Control) containing 10-20 pg of a purified plasmid equipped with the appropriate antibiotic resistance marker in place of the TOPO-activated TA vector.

4. Mix the reactions gently and incubate them at room temperature for $5 \mathrm{~min}$. Transfer the reactions into ice.

The TOPO cloning reaction can be as short as 30 sec or as long as $30 \mathrm{~min}$. The longer the PCR products, the longer the time required to obtain the maximum number of transformants.

5. Transfer $2 \mu \mathrm{L}$ of each of the reactions (Step 3 ) into separate vials of chemically competent OneShot TOP10 bacteria (Life Technologies) or equivalent. Incubate the transformation reactions on ice for $5 \mathrm{~min}$.

6. Shock the cells for exactly $30 \mathrm{sec}$ at $42^{\circ} \mathrm{C}$ and immediately return the cells to ice and add $250 \mu \mathrm{L}$ of SOC medium at room temperature.

7. Close the tube securely and then incubate it for $30 \mathrm{~min}$ at $37^{\circ} \mathrm{C}$, with gentle shaking.

8. Plate $50-\mu \mathrm{L}$ aliquots of the transformed bacteria on prewarmed agar plates containing $75-100 \mu \mathrm{g}$ of ampicillin. Incubate the cultures overnight at $37^{\circ} \mathrm{C}$.

After overnight incubation at $37^{\circ} \mathrm{C}$ and if everything has gone to plan, large numbers of transformed colonies will have been generated by the test reaction and the Positive Control. Very few colonies should be present on the plate containing the Background Control.

9. Make plasmid minipreps from cultures established from six well-isolated colonies on the Test Reaction plate. Cleave the DNAs with restriction enzymes that cleave within the multiple cloning sites flanking the insert in the plasmid. Run an agarose gel to confirm that the size of the cloned fragment of amplified DNA is correct.

The topoisomerase of vaccinia virus (see Box 1), like other type IB topoisomerases, relaxes DNA supercoils by transiently breaking and rejoining one strand of the DNA duplex. Nicking of the DNA duplex occurs as a result of nucleophilic attack on the DNA phosphodiester bond by the $\mathrm{OH}$ group of tyrosine 274 of the topoisomerase. Cleavage of the target DNA strand occurs with high 


\section{BOX 1. VACCINIA VIRUS}

Edward Jenner's introduction of vaccination against smallpox in 1796 led, $181 \mathrm{yr}$ later, to the complete eradication of the disease from the human population-surely one of the greatest achievements of medicine. Jenner's vaccine strain was derived from a pustule on the hand of a dairymaid, resulting, Jenner thought, from milking animals infected with cowpox. However, it now seems more likely from both pathological behavior and genomic analysis (Gubser et al. 2004) that the vaccine strain is either a hybrid between cowpox and smallpox, or a strain of the now extinct horsepox, or perhaps an attenuated strain of smallpox itself (Baxby 1977, 1981, 1999; Razzell 1998). Whatever its origin, vaccinia virus has found a new usefulness as a vector for mammalian expression and as the source of DNA topoisomerase, a 314-amino-acid protein that is the cornerstone of a rapid, simple method (TOPO cloning) to precisely join together segments DNA (Shuman 1994).

specificity at a pentapyrimidyl tract $5^{\prime}(\mathrm{C} / \mathrm{T}) \mathrm{CCTT}^{-}$, creating a stable $3^{\prime}$-phosphotyrosyl-DNA intermediate (Shuman et al. 1989). Because bond energy is conserved, the reaction is readily reversible and the phosphotyrosyl-DNA intermediate can either (i) catalyze reformation of the original duplex or (ii) create a recombinant DNA by forming a phosphodiester bond with an acceptor DNA with a $5^{\prime}-\mathrm{OH}$ tail complementary to that of the donor complex (see Fig. 1).

The specificity and versatility of the TOPO cleavage/ligation reaction led to the development of the family of plasmid cloning vectors that are manufactured and sold [at the time of this initial writing] by Life Technologies as TOPO phosphotyrosyl-plasmid DNA intermediates that can be ligated to DNA sequences with compatible ends in a reaction that is complete in only $5 \mathrm{~min}$ at room temperature (see the section TOPO Tools in Introduction: A Guide to Cloning the Products of Polymerase Chain Reactions [Green and Sambrook 2021]). Life Technologies markets preactivated vectors as components of kits designed for specific cloning purposes. For example, the TA Cloning Kit contains a topoisomerase-activated vector to clone PCR-generated DNAs carrying unpaired 3'-terminal adenosyl residues. Figure 2 presents diagrams of the ligation reactions used in three systems available from Life Technologies for TA cloning, blunt-end cloning and directional blunt-end cloning. Kits are also available for cloning "long" DNAs $(>1 \mathrm{~kb})$, and for cloning of PCR-derived DNAs in sequencing vectors and in pro and eukaryotic expression vectors. Check online for a full list of vectors available. Other manufacturers also sell topoisomerase-based cloning kits.

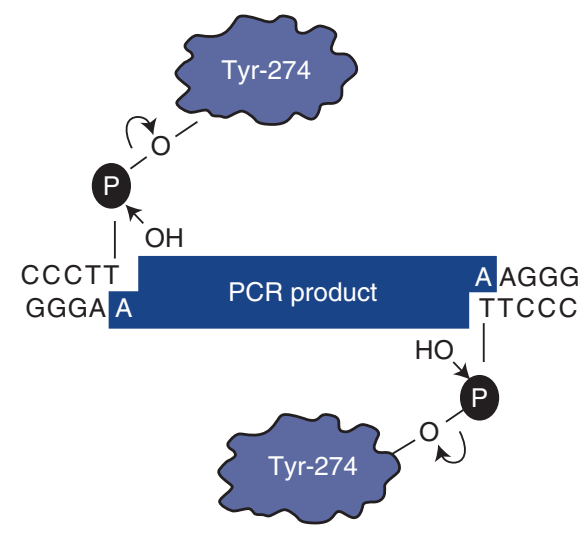

FIGURE 1. Vaccinia topo. TOPO TA cloning. The nontemplate-dependent terminal transferase activity of Taq polymerase adds a single $\mathrm{dA}$ to the $3^{\prime}$ ends of PCR products. The linear TOPO TA cloning vector contains overhanging $3^{\prime}$-dT residues and is "TOPO-activated" (i.e., TOPO is attached via a $3^{\prime}$-phosphotyrosyl linkage), enabling it to ligate efficiently with PCR products having single 3'-dA overhangs on both sides. The $5^{\prime} \mathrm{OH}$ of each end of the PCR product can attack the phosphotyrosyl bond between the vector DNA and TOPO, resulting both in the release of TOPO molecules and the production of a doubly nicked, circular, recombinant molecule (not shown). (Reproduced from Invitrogen 2002, part of Life Technologies, 2002.) 
A Topoisomerase I recognition sites

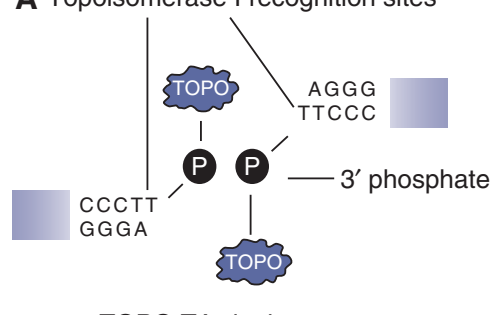

TOPO TA cloning vector

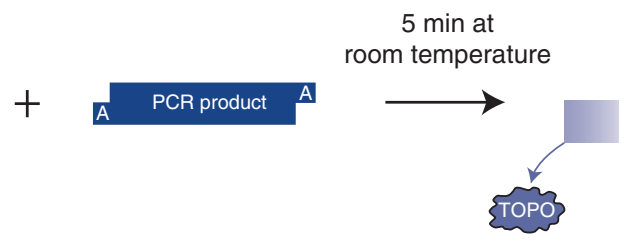

Taq-amplified PCR product

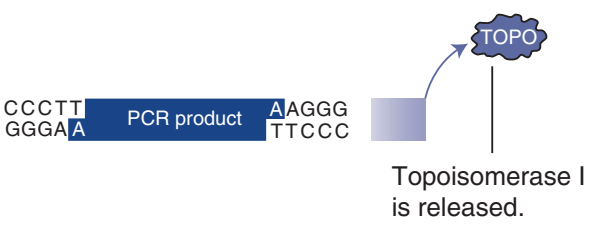

Ligation is complete.

B Topoisomerase I recognition sites

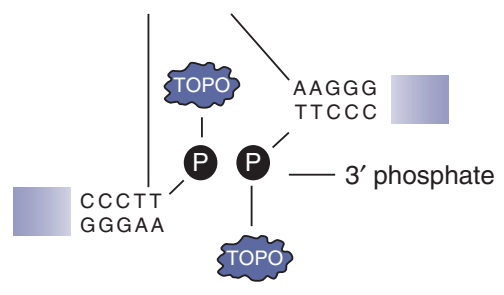

Zero blunt TOPO vector

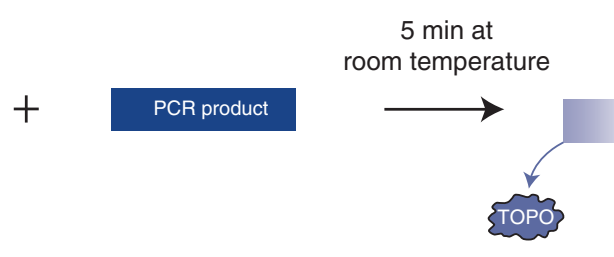

Blunt-end PCR product

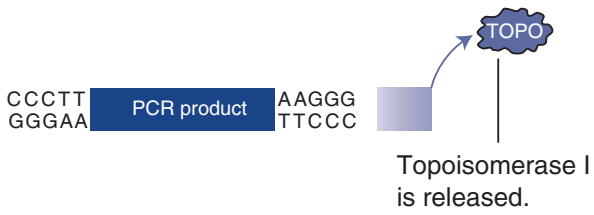

Ligation is complete.

C Topoisomerase I recognition sites

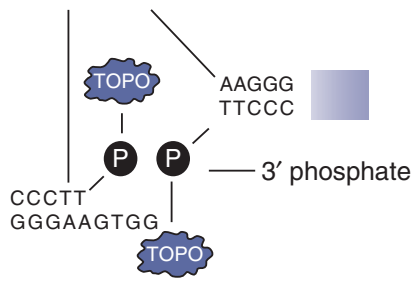

Directional TOPO cloning vector

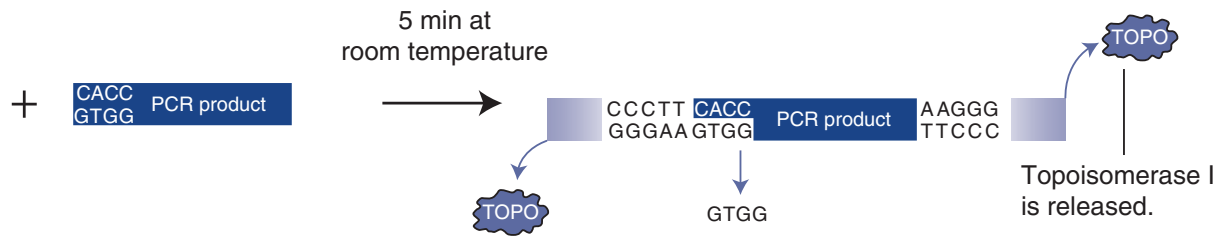

Blunt-end PCR product (designed with CACC at the

$5^{\prime}$ end, no modification at the $3^{\prime}$ end)
Extra GTGG released

Ligation is complete.

FIGURE 2. TOPO cloning. (A) TOPO TA cloning of Taq-amplified DNA. (B) Zero blunt TOPO cloning: blunt-end DNA. (C) Directional TOPO cloning: blunt-end DNA. (Reproduced from Life Technologies [Invitrogen].)

LB (Luria-Bertani) Liquid Medium

Reagent

Amount to add

$\mathrm{H}_{2} \mathrm{O}$

$950 \mathrm{~mL}$

Tryptone

$10 \mathrm{~g}$

$\mathrm{NaCl}$

$10 \mathrm{~g}$

Yeast extract

$5 \mathrm{~g}$

Combine the reagents and shake until the solutes have dissolved. Adjust the $\mathrm{pH}$ to 7.0 with $5 \mathrm{~N} \mathrm{NaOH}(\sim 0.2 \mathrm{~mL})$. Adjust the final volume of the solution to $1 \mathrm{~L}$ with $\mathrm{H}_{2} \mathrm{O}$. Sterilize by autoclaving for $20 \mathrm{~min}$ at $15 \mathrm{psi}\left(1.05 \mathrm{~kg} / \mathrm{cm}^{2}\right)$ on liquid cycle.

For solid medium, see the recipe entitled "Media containing agar or agarose." 
M.R. Green and J. Sambrook

\section{Media Containing Agar or Agarose}

Prepare liquid media according to the recipe given. Just before autoclaving, add one of the following:

Bacto agar (for plates)

$15 \mathrm{~g} / \mathrm{L}$

Bacto agar (for top agar)

$7 \mathrm{~g} / \mathrm{L}$

Agarose (for plates)

$15 \mathrm{~g} / \mathrm{L}$

Agarose (for top agarose)

$7 \mathrm{~g} / \mathrm{L}$

Sterilize by autoclaving for $20 \mathrm{~min}$ at $15 \mathrm{psi}\left(1.05 \mathrm{~kg} / \mathrm{cm}^{2}\right)$ on liquid cycle. When the medium is removed from the autoclave, swirl it gently to distribute the melted agar or agarose evenly throughout the solution. Be careful! The fluid may be superheated and may boil over when swirled. Before adding thermolabile substances (e.g., antibiotics), allow the medium to cool to $50^{\circ} \mathrm{C}-60^{\circ} \mathrm{C}$, and mix the medium by swirling to avoid producing air bubbles.

Before pouring the plates, set up a color code (e.g., two red stripes for LB-ampicillin plates; one black stripe for LB plates, etc.), and mark the edges of the plates with the appropriate colored markers. Pour plates directly from the flask; allow $\sim 30-35 \mathrm{~mL}$ of medium per 90-mm plate. To remove bubbles from the medium in the plate, flame the surface of the medium with a Bunsen burner before the agar or agarose hardens. When the medium has hardened completely, invert the plates and store them at $4^{\circ} \mathrm{C}$ until needed.

The plates should be removed from storage $1-2 \mathrm{~h}$ before they are used. If the plates are fresh, they will "sweat" when incubated at $37^{\circ} \mathrm{C}$. When this condensation drops on the agar/agarose surface, it allows bacterial colonies or bacteriophage plaques to spread and increases the chances of cross-contamination. This problem can be avoided by wiping off the condensation from the lids of the plates and then incubating the plates for several hours at $37^{\circ} \mathrm{C}$ in an inverted position before they are used. Alternatively, remove the liquid by shaking the lid with a single, quick motion. To minimize the possibility of contamination, hold the open plate in an inverted position while removing the liquid from the lid.

\section{SOB Medium}

Per liter: To $950 \mathrm{~mL}$ of deionized $\mathrm{H}_{2} \mathrm{O}$, add:

Tryptone

Yeast extract

$\mathrm{NaCl}$

Shake until the solutes have dissolved. Add $10 \mathrm{~mL}$ of a $250 \mathrm{~mm}$ solution of $\mathrm{KCl}$. (This solution is made by dissolving $1.86 \mathrm{~g}$ of $\mathrm{KCl}$ in $100 \mathrm{~mL}$ of deionized $\mathrm{H}_{2} \mathrm{O}$.) Adjust the $\mathrm{pH}$ of the medium to 7.0 with $5 \mathrm{~N} \mathrm{NaOH}(\sim 0.2 \mathrm{~mL})$. Adjust the volume of the solution to $1 \mathrm{~L}$ with deionized $\mathrm{H}_{2} \mathrm{O}$. Sterilize by autoclaving for 20 min at $15 \mathrm{psi}\left(1.05 \mathrm{~kg} / \mathrm{cm}^{2}\right)$ on liquid cycle. Just before use, add $5 \mathrm{~mL}$ of a sterile solution of $2 \mathrm{M} \mathrm{MgCl}_{2}$. (This solution is made by dissolving $19 \mathrm{~g}$ of $\mathrm{MgCl}_{2}$ in $90 \mathrm{~mL}$ of deionized $\mathrm{H}_{2} \mathrm{O}$. Adjust the volume of the solution to $100 \mathrm{~mL}$ with deionized $\mathrm{H}_{2} \mathrm{O}$ and sterilize by autoclaving for 20 min at $15 \mathrm{psi}$ $\left[1.05 \mathrm{~kg} / \mathrm{cm}^{2}\right]$ on liquid cycle.)

For solid medium, please see the recipe entitled "Media containing agar or agarose." $<\mathrm{R}>$ 


\section{SOC Medium}

Per liter: To $950 \mathrm{~mL}$ of deionized $\mathrm{H}_{2} \mathrm{O}$, add:

Tryptone

Yeast extract

SOC medium is identical to SOB medium, except that it contains $20 \mathrm{~mm}$ glucose. To prepare $\mathrm{SOB}$ medium, combine the above ingredients and shake until the solutes have dissolved. Add $10 \mathrm{~mL}$ of a $250 \mathrm{~mm}$ solution of $\mathrm{KCl}$. (This solution is made by dissolving $1.86 \mathrm{~g}$ of $\mathrm{KCl}$ in $100 \mathrm{~mL}$ of deionized $\mathrm{H}_{2} \mathrm{O}$.) Adjust the $\mathrm{pH}$ of the medium to 7.0 with $5 \mathrm{~N}$ $\mathrm{NaOH}(\sim 0.2 \mathrm{~mL})$. Adjust the volume of the solution to $1 \mathrm{~L}$ with deionized $\mathrm{H}_{2} \mathrm{O}$. Sterilize by autoclaving for $20 \mathrm{~min}$ at $15 \mathrm{psi}\left(1.05 \mathrm{~kg} / \mathrm{cm}^{2}\right)$ on liquid cycle. Just before use, add $5 \mathrm{~mL}$ of a sterile solution of $2 \mathrm{M} \mathrm{MgCl}_{2}$. (This solution is made by dissolving $19 \mathrm{~g}$ of $\mathrm{MgCl}_{2}$ in $90 \mathrm{~mL}$ of deionized $\mathrm{H}_{2} \mathrm{O}$. Adjust the volume of the solution to $100 \mathrm{~mL}$ with deionized $\mathrm{H}_{2} \mathrm{O}$ and sterilize by autoclaving for $20 \mathrm{~min}$ at $15 \mathrm{psi}\left[1.05 \mathrm{~kg} / \mathrm{cm}^{2}\right]$ on liquid cycle.)

After the SOB medium has been autoclaved, allow it to cool to $60^{\circ} \mathrm{C}$ or less. Add $20 \mathrm{~mL}$ of a sterile $1 \mathrm{~m}$ solution of glucose. (This solution is made by dissolving $18 \mathrm{~g}$ of glucose in $90 \mathrm{~mL}$ of deionized $\mathrm{H}_{2} \mathrm{O}$. After the sugar has dissolved, adjust the volume of the solution to $100 \mathrm{~mL}$ with deionized $\mathrm{H}_{2} \mathrm{O}$ and sterilize by passing it through a $0.22-\mu \mathrm{m}$ filter.)

\section{REFERENCES}

Baxby D. 1977. The origins of vaccinia virus. J Infect Dis 136: 453-455.

Baxby D. 1981. Jenner's smallpox virus: The riddle of vaccinia virus and its origins. Heineman Educational Books, London.

Baxby D. 1999. The origins of vaccinia virus-An even shorter rejoinder. Soc Hist Med 12: 139.

Green MR, Sambrook J. 2021. A guide to cloning the products of polymerase chain reactions. Cold Spring Harb Protoc doi: 10.1101/pdb.top 101345.

Gubser C, Hue S, Kellam P, Smith GL. 2004. Poxvirus genomes: A phylogenetic analysis. J Gen Virol 85: 105-117.
Invitrogen. 2002. pENTR directional TOPO cloning kits (version B, July 9, 2002, 25-0434). Invitrogen Life Technologies, Inc., Rockville, MD.

Razzell P. 1998. The origins of vaccinia virus-A brief rejoinder. Soc Hist Med 11: 107-108.

Shuman S. 1994. Novel approach to molecular cloning and polynucleotide synthesis using vaccinia DNA topoisomerase. J Biol Chem 269: 32678-32684.

Shuman S, Kane EM, Morham SG. 1989. Mapping the active-site tyrosine of vaccinia virus DNA topoisomerase I. Proc Natl Acad Sci 86: 9793-9797. 


\section{Cloning Polymerase Chain Reaction (PCR) Products: TOPO TA Cloning}

Michael R. Green and Joseph Sambrook

Cold Spring Harb Protoc; doi: 10.1101/pdb.prot101311

\begin{tabular}{|c|c|}
\hline $\begin{array}{r}\text { Email Alerting } \\
\text { Service }\end{array}$ & Receive free email alerts when new articles cite this article - click here. \\
\hline $\begin{array}{l}\text { Subject } \\
\text { Categories }\end{array}$ & $\begin{array}{l}\text { Browse articles on similar topics from Cold Spring Harbor Protocols. } \\
\text { Cloning of PCR Products (20 articles) } \\
\text { Molecular Biology, general (1293 articles) } \\
\text { Plasmids (154 articles) } \\
\text { Polymerase Chain Reaction (PCR) (139 articles) } \\
\text { Polymerase Chain Reaction (PCR), general (184 articles) }\end{array}$ \\
\hline
\end{tabular}

